\begin{tabular}{l|c|c|}
\hline DE & DE GRUYTER \\
$\mathrm{G}$ & EPEN \\
& DOI 10.1515/ethemes-2016-0019
\end{tabular}

\title{
THE IMPORTANCE OF MOBILE BANKING IN THE NISAVA DISTRICT
}

\author{
Miloš Stojanović \\ University of Nis, Faculty of Economics, Republic of Serbia \\ \ilos.s87@hotmail.com \\ Marina Đorđević \\ University of Nis, Faculty of Economics, Republic of Serbia \\ $\triangle$ marina.dj@ptt.rs
}

UDC

004.738.5:3

$36.71(497.1$

1 Niš)

Original

scientific

paper

Received:

09.04.2016

Accepted:

26.09.2016

\begin{abstract}
Changes in the world of technology have enabled banks to use new channels for distribution of banking services to its clients. With the appearance of of smart phones, WEB mobile banking is developed,and it provides a possibility for greater integration between the bank and the client. WEB mobile banking is increasingly gaining in importance, especially in developed countries, while this process in our country is much slower. The aim of this paper is to point out the benefits that WEB mobile banking offer to users, but also to point out its weak presence in the Nisava District and Serbia in general. Also the identification of the main reasons forweak presence of mobile banking in our region, aims to point out in which way can in the future this banking be quickly disseminated among users. In order to achieve the defined objectives, the authors used descriptive method, method of compilation, comparison, deduction and induction and statistical method which is used for testing of independence between variables and calculation of coefficient of contingency.
\end{abstract}

Keywords: WEB mobile banking, e-banking, Serbia, Nišava district.

JEL classification: C10, D12,G21

\section{Introduction}

The development of techniques and technology had a great impact on changes in the banking business and in the structure of services that banks offer to their clients.First of all, increased use of computers and the Internet has influenced the development of internet banking, and later occurrence of smart phones, which have 
performance power as most computers, has led to the development of WEB mobile banking (m-banking WEB) as a subspecies of internet banking.Besides all the the advantages that internet banking offers its customers, mobile banking provides additional advantages in the sense that services can be used anywhere, at any time of the day, when the client is in motion.

Before the advent of smart phones, there have been attempts for development of mobile banking, but they were mostly unsuccessful.The main reasons for the failure of mobile banking in the period before the advent of smart phones, there may be mentioned the small screens of mobile phones and their poor performance, which made it difficult to use the services of of mobile banking.Only the SMS banking as mobile banking segment successfully functioned even before there was the massive use of smartphones worldwide. It enables its clients to access to account balance, both at the client's request (pull technology), and by sending a notice by the bank to the client on payments to his account and the account balance (Push technology).

The appearance of smart phones, led to the revolution and the development of mobile banking applications, which enable its customers to easily conduct transactions by a mobile phone. These applications provide customers different kinds of services, and often they offer the following services: paying bills, checking account balances and credit cards, access to the exchange rate, exchange operations, etc.

Due to the ease of conducting transactions by mobile phone and lower transaction costs, in the world this type of banking is developing rapidly, while in our country this development is much slower. However, the adoption of appropriate legislation, raising confidence in the institutions and in the banking system, as well as increasing the level of education of the population in Serbia, can have positive effects in terms of increasing the number of users of mobile banking services.

\section{Electronic Banking}

In contemporary conditions banks are facing heavy competition, both among themselves and with other financial institutions, which in modern conditions as part of their service packages offer a number of services, which fall within the set of banking services.In order to oppose to the competition, they are forced constantly to monitor the changes occurring in the business world and the world of computer technology and to develop a new services in order to provide a higher level of satisfaction of its clients, as well as a higher degree of integration with its customers (Curwen, Whalley, 2010). 
The growing use of the Internet in modern business worldwide, has led to the development of electronic banking. Today, both in the world and in our country all banks offer electronic banking services to their clients.According to Vasant (2010) electronic banking means providing new and traditional services to clients through electronic interactive communication channels.In this way, customers are given the possibility to carry out different types of banking transactions via the Internet network without going to the bank, thus saving their time, but also reduce their costs, given that in the realisation of this transactions fee for a large number of transactions, banks do not charge or charge cheaper compared to conventional transactions conducted on bank counters (Barnes, Scornavacca, 2006).

Through the electronic banking customers can perform financial transactions such as payments, money transfers to another account, they can pay bills that were previously defined (standing order), monitor the movement of the exchange rate and perform exchange operations, to have insight into the daily changes on their accounts, and to monitor the condition of the loans if they have them (www.tvojnovac.nbs.rs).

Electronic banking is a concept that encompasses the following aspects of banking:

- Internet banking - through the Internet network clients via a computer can $\log$ in to the site of the Bank, whose clients are and then conduct transactions in accordance with their needs (Barjaktarović, 2009, p. 17-18);

- WEB mobile banking - gives the possibility to customers by using a special application of his/her bank, which is installed on the phone, to access to their accounts and perform appropriate transactions;

- Telephone banking - gives the possibility to client to conduct banking transactions via telephone conversation with the bank agent, as well as to obtain information about other services offered by the Bank (Šalić, 2012, p. 285);

- WEB TV Banking - a new generation of television that has the ability to connect to the Internet, gives the possibility of realisation of e-banking services. This form of the electronic banking is designed for users who use less or not use computers (Sanders, 2014, pp. 86-109).

- SMS standing orders - on the basis of the signed contract, the bank transfers from the account of the client the funds in favour of service providers (creditor) per month and notifies the client about the settlement of obligations by SMS (www.bancaintesa.rs).

In a broader sense electronic banking in addition to the above aspects of banking, includes: 
- The use of E-banking terminals - these self-service devices in bank branch offices allow customers to raise funds, have access to the account balance, as well as to transfer funds from your account to another (Mambi, 2010, p. 122);

- Payment of goods and services ordered via the Internet by debit and credit cards from clients - clients after they order goods and services via Internet, enter their card number, after which the money from their accounts is transferred to the account of the seller (Mohapatra, 2013, p. 88- 90).

All the mentioned forms of the electronic banking from year to year gain in importance, especially in developed countries. So in countries like Denmark, Norway and Finland almost 90\% of the population between 16 and 74 use the Internet for implementation of electronic banking services (ec.europa.eu).

\section{WEB Mobile Banking}

The appearance of portable computers, tablets and smartphones, and increasing their use, have created the basis for the creation of new virtual channels, through which performs financial services by banks (Hadžić, Mladenović, 2014).Experts from the IT sector, in cooperation with bankers have developed applications, whose installation on mobile phones, with Android and IOS operating systems, allows users to access to their bank accounts and implement the transaction in accordance with their needs(Barnes, 2003).

In this manner customers are given the possibility at any time to implement banking transactions and from any location, which particularly stands out as an advantage of this aspect of banking(King, 2013). From the aspect of the bank's special importance of of this form of banking is reflected in the fact that this way of realisation of the transaction will provide a basis for reducing the cost of the bank's operations, but also ensures a higher degree of integration of the bank with the client, providing a higher degree of customer loyalty to the bank(Laukannen, 2007).

According to Drexelius and Herzig (2001) mobile banking can be defined as a segment of electronic banking, which gives customers the ability to perform banking transactions via mobile devices (mobile phones and tablets), anywhere and anytime.

In a broader sense mobile banking besides WEB mobile banking, includes SMS mobile banking. SMS mobile banking gives the possibility of (Duggal, 2013):

- Checking account balances by sending messages (PUSH technology) and

- Receive information or notifications from the bank on payments or payoffs from the account (PULL technology). 
This type of service is much more widespread in our country and in the world compared to the mobile banking service WEB.

As basic characteristics of WEB mobile banking the following can be mentioned (Sanders, 2014, pp. 86-109):

- The possibility of wide use - the client can from any location to carry out transactions that are required;

- Immediacy - the possibility that the client at any time realises transaction;

- Automatic and instant connection with the bank, without the need of going to the banking counters;

- Proactive functionality - customers can choose the service of the Bank, on which they would like to be informed (usually via SMS).

By analysing services provided by banks in Serbia within WEB mobile banking to individuals, the following types of services are offered:

- Insight into the balance and turnover of accounts that customers have with the bank, as well as the accounts for which the client is authorised;

- Insight into the balance and turnover of payment cards;

- Insight into the balance and turnover on loans;

- Transfer funds between own accounts of the client;

- Repayment of liabilities on credit cards;

- Monitoring of the exchange rate;

- Exchange operations or the operations of buying and selling of foreign currencies within the account with the same ID number;

- Non-cash payments;

- Search the nearest ATMs and bank branches;

- Service use savings and loan calculators;

- Contracting term deposit.

Addition to the listed services, special attention is captured by service "Photopay“ which is currently in Serbia offered only by ERSTE bank and only for android devices.This service gives customers the ability to take photos of their accounts they want to pay, by their phones, and based on the photos, the payment order is automatically completed.After this, customers can check the information that is automatically entered in the account and make corrections if it is necessary, and after that they sent order to the bank and through the application they can determine from which account they want to make the payment, if they have multiple accounts with the same bank.

\section{The Importance of the WEB Mobile Banking Services in the World}


Ease of use, the possibility of permanent control over transactions, the faster pace of life and work, as well as the need for costs reduction have had a huge impact on the WEB mobile banking and has been quickly accepted by clients (Becker, 2014).This is evidenced by the data from the website of "statista" (www.statista.com), which show that the number of users of these services increases every year. For example, in the United States in 2009 WEB mobile banking services were used only by $16 \%$ of the population, but in 2013 the number of users increased to 38\% and in 2016 the number of users increased further to $51 \%$ of the total population.

The largest number of users of mobile banking application is in Indonesia, where in 2014, 77\% of people said they used these applications.Also in China this form of banking is extremely present, given that the application for implementation of banking transactions by phone uses about $73 \%$ of people. Besides the already mentioned countries more than 50\% of the population already in 2014 used this application in India, Singapore, Malaysia and Thailand. On the basis of the data presented, it can be seen that Asian countries are leading when it comes to WEB mobile banking services.

In the European Union as it can be seen in Graph. 1, mobile banking WEB applications on their phones were used by 38\% of the population in 2014. This is a much lower percentage than in mentioned countries, but it is certainly convenient that in the European Union also, especially in developed EU countries like the Netherlands, Germany, Austria, Luxembourg, the number of users is constantly increasing.

\section{Graph 1 Using WEB Application Mobile Banking in Selected Countries of the European Union in 2014}

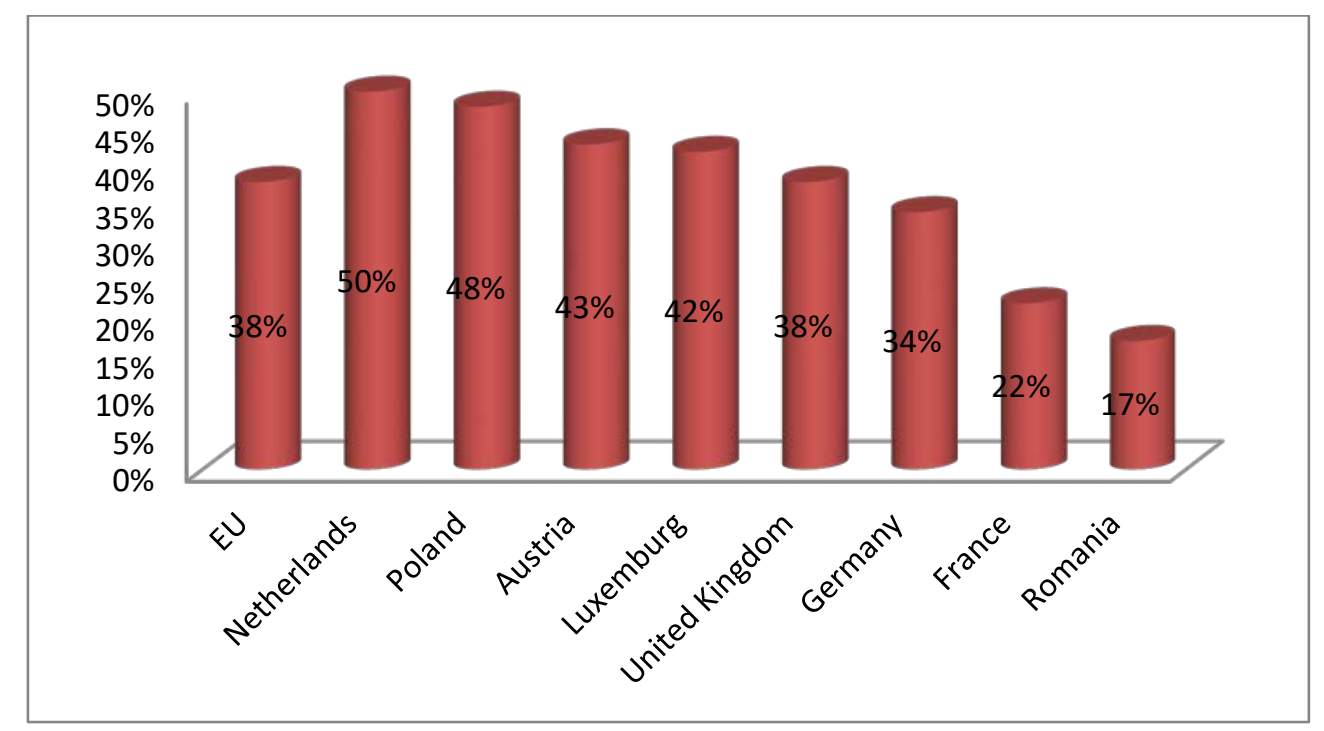


Source: http://www.statista.com/, graphics illustrated by the authors.

As it can be seen from the graphs the greatest significance of mobile banking in the countries of the European Union is in the Netherlands, where about $50 \%$ of the population uses the services of WEB mobile banking, and the smallest character of the observed countries is in Romania, where only $17 \%$ of the population uses these services.

\section{WEB Mobile Banking in Serbia}

Although all banks in Serbia offer mobile banking service to its customers, it is still not enough widespread among users. As the basic factors that influence that users choose to use the services in the bank's premises are primarily insufficient knowledge of modern technologies and the lack of information on modern technologies.

Table 1 Trends in the total number of clients of banks and the number of clients with whom the bank has contracted the use of mobile banking services in Serbia in the period 2013-2015

\begin{tabular}{|c|c|r|r|}
\hline Year & Quater & Toatal number of clients $^{1}$ & Mobile banking \\
\hline \multirow{4}{*}{$\mathbf{2 0 1 3}$} & I & $8,446,666$ & 72,252 \\
\cline { 2 - 4 } & II & $8,408,376$ & 81,374 \\
\cline { 2 - 4 } & III & $8,452,502$ & 87,091 \\
\cline { 2 - 4 } & IV & $8,475,949$ & 97,150 \\
\hline \multirow{4}{*}{$\mathbf{2 0 1 4}$} & I & $8,517,231$ & 103,212 \\
\cline { 2 - 4 } & II & $8,561,581$ & 110,721 \\
\cline { 2 - 4 } & III & $8,671,761$ & 137,157 \\
\cline { 2 - 4 } & IV & $8,811,973$ & 179,724 \\
\hline \multirow{3}{*}{$\mathbf{2 0 1 5}$} & I & $8,774,395$ & 218,456 \\
\cline { 2 - 4 } & II & $8,865,687$ & 275,668 \\
\cline { 2 - 4 } & III & $8,921,967$ & 324,103 \\
\cline { 2 - 4 } & IV & $9,032,298$ & 464,167 \\
\hline
\end{tabular}

\footnotetext{
${ }^{1}$ Clients who have accounts with several banks were counted once, while in those cases where the client has accounts in a number of banks, is included in the total number of clients in each of these banks.
} 
Source: National Bank of Serbia Payment System Department. Available on the site:http://www.nbs.rs/export/sites/default/internet/latinica/35/statistika/pokazatelji/broj_kor isnika.xls, access date 01.04.2016.

However, it is commendable that from year to year the number of users of the Internet and mobile banking services increases, which indicates that the level of computer and technology literacy, as well as confidence in the banking system itself increases. The great influence on the fact that the number of mobile banking service users increases has had aggressive marketing bank campaign about these services through the media but also increases the number of users of smartphones.

In Table 1, there can be seen the trend of growth in the number of clients who have contracted with the bank to use mobile banking services, so the number of users in the last quarter of 2015 was $112.48 \%$ higher compared to the first quarter of 2013.

However, if we look at the participation of the number of mobile banking users compared to the total number of clients, it is a significant low level in the last quarter of 2015, this share amounted to $5.14 \%$. However, if we compare this figure with a share of $0.86 \%$, which was in the first quarter of 2013 , we can see a significant shift.

\section{Analysis of the Use of Mobile Banking in the Nisava District}

With the aim to obtain insight into the acceptance of mobile banking services in the Nisava District, a survey was conducted in the City of Nis, as well as in the municipality of Gadzin Han, Aleksinac and Svrljig above subjects of different ages and education in the period from 1-31 March 2016.The analysis included 800 respondents, of whom there were 440 men and 360 women, who had accounts in banks.

\section{Graph 2 Use of WEB Mobile Banking in the Nisava District}

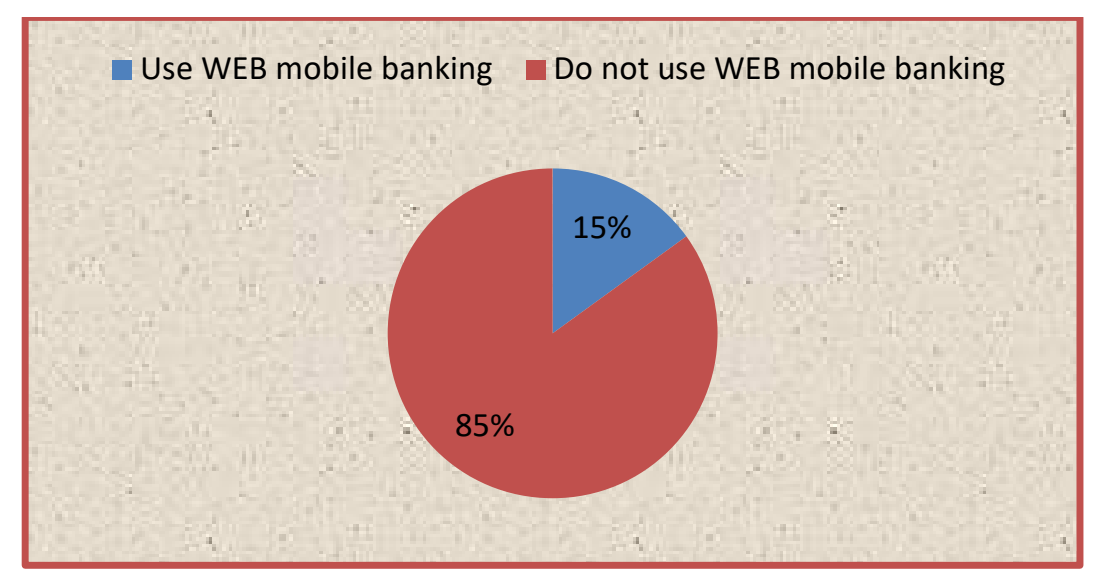


Source: Graph illustrated by the authors based on the results of the survey.

The conducted survey showed that WEB mobile banking services were still underutilised in the Nisava region, given that only 14.88\% of respondents (119 of them) declared that use WEB mobile banking, while even 681 respondents did not use these services, as it can be seen in Graph 2.

The situation is much more favourable when it comes to SMS Banking, as much as $90 \%$ of respondents said they used this service, ie received notification of changes to their account balance, as well as sending messages received from the bank information on the status of their account.

Regarding the structure of the use of toward the poles, 72 men and 47 women said that they used the services of WEB mobile banking.This means that in relation to the total number of male respondents, $16.36 \%$ of them said that they used these services, while in the group of women, services were used by $13 \%$.

The answer to the question of whether the gender structure has an impact on the use of mobile banking is obtained through the test of independence. For the implementation of this test SPSS programme was used. The contingency Table 2 shows the received and expected frequencies.

Table 2 Contingency Table of Gender Structure and the Number of Users of WEB Mobile Banking

\begin{tabular}{|c|c|c|c|c|c|}
\hline & & & \multicolumn{2}{|c|}{ Use mBanking } & \multirow[t]{2}{*}{ Total } \\
\hline & & & Yes & No & \\
\hline \multirow{8}{*}{ Sex } & \multirow{5}{*}{ Man } & Count & 72 & 368 & 440 \\
\hline & & \% within Sex & $16.4 \%$ & $83.6 \%$ & $100.0 \%$ \\
\hline & & $\begin{array}{l}\text { \% within } \\
\text { UseMBanking }\end{array}$ & $60.5 \%$ & $54.0 \%$ & $55.0 \%$ \\
\hline & & $\%$ of Total & $9.0 \%$ & $46.0 \%$ & $55.0 \%$ \\
\hline & & Count & 47 & 313 & 360 \\
\hline & \multirow{3}{*}{ Woman } & \% within Sex & $13.1 \%$ & $86.9 \%$ & $100.0 \%$ \\
\hline & & $\begin{array}{l}\text { \% within } \\
\text { UseMBanking }\end{array}$ & $39.5 \%$ & $46.0 \%$ & $45.0 \%$ \\
\hline & & $\%$ of Total & $5.9 \%$ & $39.1 \%$ & $45.0 \%$ \\
\hline \multirow{4}{*}{ Total } & & Count & 119 & 681 & 800 \\
\hline & & \% within Sex & $14.9 \%$ & $85.1 \%$ & $100.0 \%$ \\
\hline & & $\begin{array}{l}\text { \% within } \\
\text { UseMBanking }\end{array}$ & $100.0 \%$ & $100.0 \%$ & $100.0 \%$ \\
\hline & & $\%$ of Total & $14.9 \%$ & $85.1 \%$ & $100.0 \%$ \\
\hline
\end{tabular}

Source: Authors based on the results of the survey. 
Table 3 shows the results of the test statistics (Sampling realization of the test statistic and the p-value). Given that $\mathrm{p}=0.191<0.05$, it can be concluded that gender has no influence on whether a person is using or not using mobile banking.

Table 3 Test of Independence between Gender Structure and the Number of Users of Mobile Banking

\begin{tabular}{|c|c|c|c|}
\hline & Value & $\mathrm{df}$ & Asymp. Sig. (2-sided) \\
\hline Pearson Chi-Square & $1.711^{\mathrm{a}}$ & 1 & .191 \\
\hline Continuity Correction ${ }^{\mathrm{b}}$ & 1.460 & 1 & .227 \\
\hline Likelihood Ratio & 1.725 & 1 & .189 \\
\hline Fisher's Exact Test & & & \\
\hline Linear-by-Linear & 1.709 & 1 & .191 \\
\hline Association & & & \\
\hline $\mathrm{N}$ of Valid Cases & 800 & & \\
\hline
\end{tabular}

Source: Authors based on the results of the survey.

The obtained results of the independence of gender and use of WEB mobile banking, you can further substantiate by the graph, from which reveals that the number of women users is lower than the number of men, but the number of women respondents to the survey is also lower.

\section{Graph 3 Using WEB Mobile Banking by Gender in the Nisava District}

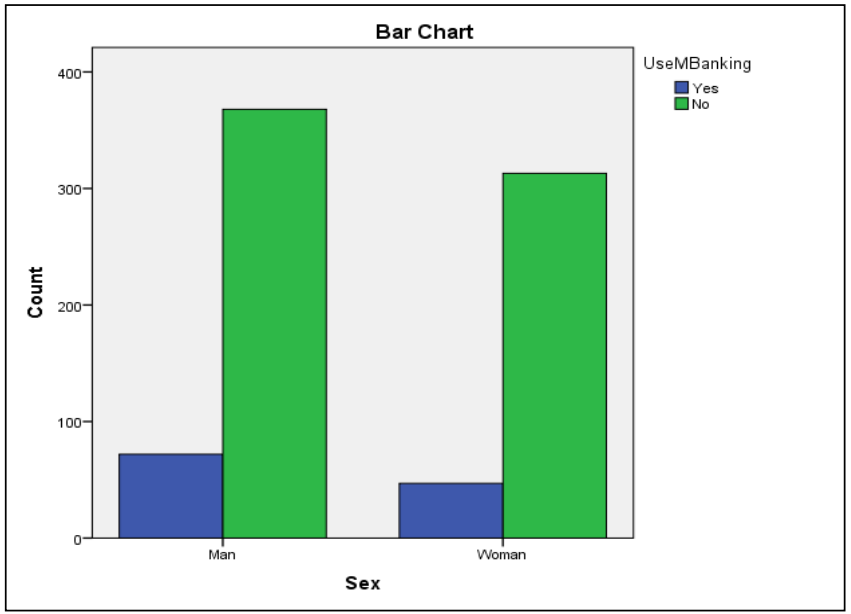

Source: Authors based on the results of the survey.

Besides the gender structure, the age structure and level of education of persons who use these banking services are important. In the world, WEB mobile banking is more accepted by the population up to 50 years and older use these services less. 
To a similar structure we came on the basis of the survey in the Nisava District.The largest number of respondents, who declared that use the benefits of these services belonged to the group between 36 and 55 years of age (51\%), while the smallest number of users among the population older than 55 years, $16 \%$ of them, as can be seen in Table 4.The age structure shows that the population between 18 and 55 years more easily accepts new technology and technique is the realisation of their financial transactions.

Table 4 Age Structure of WEB Mobile Banking Service Users in the Nisava District

\begin{tabular}{|c|c|c|}
\hline Age & $\begin{array}{c}\text { Number of } \\
\text { users }\end{array}$ & Percentage share \\
\hline $\mathbf{1 8 - 3 5}$ & 39 & $33 \%$ \\
\hline $\mathbf{3 6 - 5 5}$ & 61 & $51 \%$ \\
\hline $\mathbf{5 5}$ and more & 19 & $16 \%$ \\
\hline Total & 119 & 100 \\
\hline
\end{tabular}

Source: The authors based on the results of the survey.

As for the educational structure of mobile banking applications users, in the Nisava District, the survey showed that the largest number of users are universityeducated.Of the total respondents, 226 are university-educated, and 63 of them said that they used the WEB mobile banking services, ie of the total number of university-educated respondents $27.88 \%$ of them use this services.Of the 184 respondents who completed higher school, 21 of them said that they used these services, or $11.41 \%$ compared to the number of respondents with higher education.The largest number of respondents completed secondary education, 390 of them, but only 35 of them use mobile banking applications on their phones, meaning that only $8.97 \%$ of the total number of respondents who completed secondary school use these applications as Table 5 shows.

Table 5 Table of Contingency of Educational Structure and the Number of Users of WEB Mobile Banking

\begin{tabular}{|c|c|c|c|c|c|}
\hline & & & \multicolumn{2}{|c|}{ Use mBanking } & \multirow[t]{2}{*}{ Total } \\
\hline & & & Yes & No & \\
\hline \multirow[t]{4}{*}{ Education } & \multirow[t]{4}{*}{ Secondary } & Count & 35 & 355 & 390 \\
\hline & & $\%$ within Education & $9.0 \%$ & $91.0 \%$ & $100.0 \%$ \\
\hline & & \% within UseMBanking & $29.4 \%$ & $52.1 \%$ & $48.8 \%$ \\
\hline & & $\%$ of Total & $4.4 \%$ & $44.4 \%$ & $48.8 \%$ \\
\hline
\end{tabular}




\begin{tabular}{|c|c|c|c|c|c|}
\hline & \multirow[t]{4}{*}{ High } & Count & 21 & 163 & 184 \\
\hline & & \% within Education & $11.4 \%$ & $88.6 \%$ & $100.0 \%$ \\
\hline & & \% within UseMBanking & $17.6 \%$ & $23.9 \%$ & $23.0 \%$ \\
\hline & & $\%$ of Total & $2.6 \%$ & $20.4 \%$ & $23.0 \%$ \\
\hline & \multirow[t]{4}{*}{ Higher } & Count & 63 & 163 & 226 \\
\hline & & $\%$ within Education & $27.9 \%$ & $72.1 \%$ & $100.0 \%$ \\
\hline & & \% within UseMBanking & $52.9 \%$ & $23.9 \%$ & $28.2 \%$ \\
\hline & & $\%$ of Total & $7.9 \%$ & $20.4 \%$ & $28.2 \%$ \\
\hline \multirow{4}{*}{\multicolumn{2}{|c|}{ Total }} & Count & 119 & 681 & 800 \\
\hline & & \% within Education & $14.9 \%$ & $85.1 \%$ & $100.0 \%$ \\
\hline & & \% within UseMBanking & $100.0 \%$ & $100.0 \%$ & $100.0 \%$ \\
\hline & & $\%$ of Total & $14.9 \%$ & $85.1 \%$ & $100.0 \%$ \\
\hline
\end{tabular}

Source: The authors based on the results of the survey.

Table 6 shows the results of the test statistics (Sampling realisation of the test statistic and the p-value). Considering that the implementation of Sampling test statistics is 42,634 with the realised level of significance $p=0.000<0.05$, it can be concluded that between the level of education and the number of users of WEB mobile banking there is a strong and the statistically significant correlation.

Table 6 Test of Independence between the Educational Structure and the Number of Users of WEB Mobile Banking

\begin{tabular}{|l|c|c|c|}
\hline & Value & df & Asymp. Sig. (2-sided) \\
\hline Pearson Chi-Square & $42.634^{\mathrm{a}}$ & 2 & .000 \\
\hline Likelihood Ratio & 39.191 & 2 & .000 \\
\hline Linear-by-Linear Association & 37.181 & 1 & .000 \\
\hline N of Valid Cases & 800 & & \\
\hline
\end{tabular}

a. 0 cells $(0.0 \%)$ have expected count less than 5 . The minimum expected count is 27.37.

Source: The authors based on the results of the survey.

The high degree of dependence of these two variables can be seen on the basis of the value of the coefficient of contingency, which amounts to 0,225 to the realised level of significance $\mathrm{p}=0.000<0.05$, as can be seen from and Table 7 . 
Table 7 Contingency Coefficient of Educational Structure and the Number of Users of WEB Mobile Banking

\begin{tabular}{|ll|rr|}
\hline & & Value & Approx. Sig. \\
\hline & Phi & .231 & .000 \\
Nominal by Nominal & Cramer's V & .231 & .000 \\
& Contingency Coefficient & .225 & .000 \\
N of Valid Cases & & 800 & \\
\hline
\end{tabular}

Source: The authors based on the results of the survey.

However, if we consider only the customers who declared themselves as users of the WEB Mobile Banking Services, 53\% of them are university educated, as can be seen in Graph 4, which shows us that highly educated persons from the territory of the Nisava District easier adapt new banking technologies, compared to those with high or secondary school.

\section{Graph 4 Educational Structure of Users of Mobile Banking Application in the Nisava} District

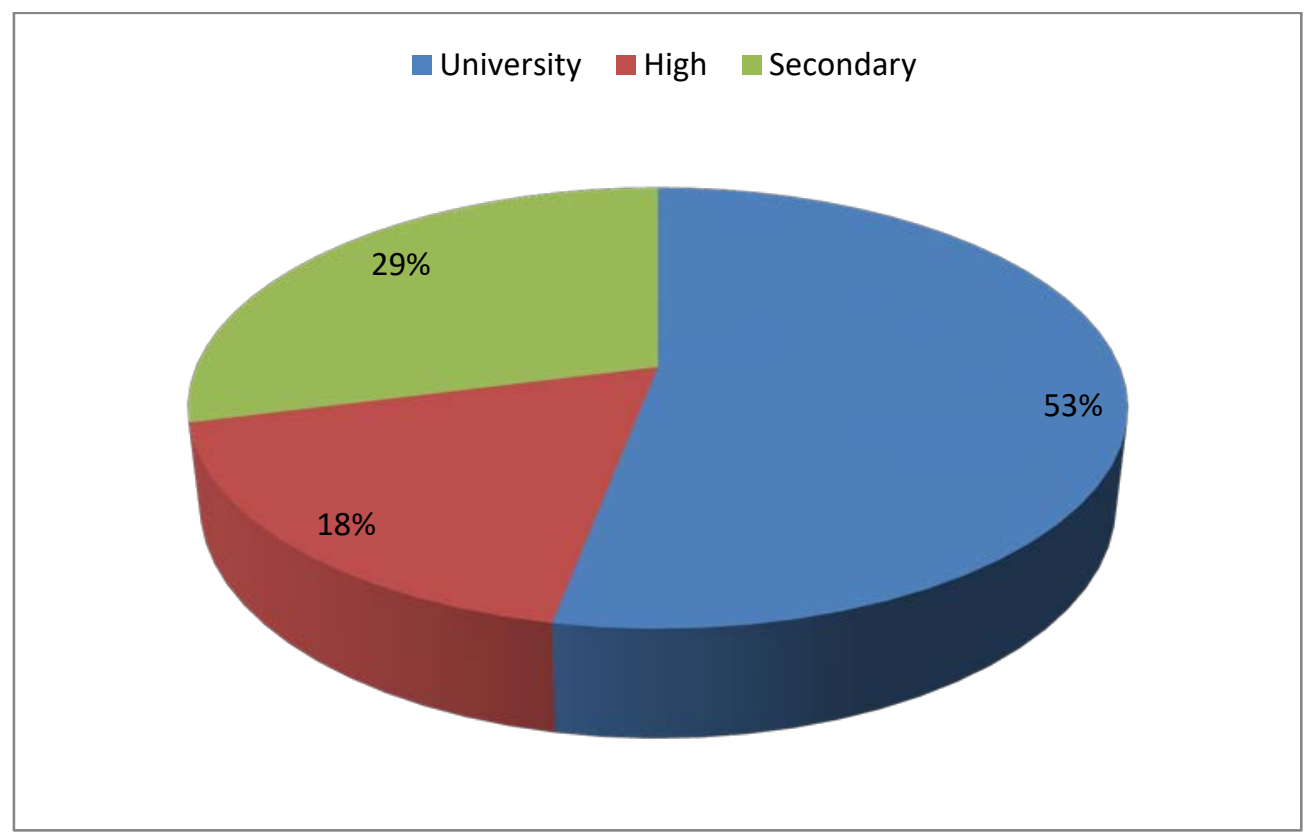

Source: Graph illustrated by the authors based on the results of the survey. 
Surveyed respondents who declared themselves as users of mobile devices in the implementation of banking transactions, mostly of the services offered use the service checks of account, which is used by $97.48 \%$ of those who identified themselves as users of services WEB mobile banking, ie 14,50\% of total respondents.Service which is also a lot accepted is payment account service, or non-cash payments, which is used by $67.23 \%$ of users, or $10 \%$ of the total number of people surveyed, while the number of users of the term deposit savings, the use of savings and loan calculators, monitoring and exchange rate, purchase of foreign currencies is significantly lower, as can be seen on the basis of the data presented in Table 8.

Table 8 The Users of WEB Mobile Banking According to the Type of Services in the Territory of the Nisava District

\begin{tabular}{|l|c|c|c|}
\hline \multicolumn{1}{|c|}{ Type of service } & $\begin{array}{c}\text { Number of } \\
\text { users }\end{array}$ & $\begin{array}{c}\text { \% relative to the } \\
\text { number of } \\
\text { respondents }\end{array}$ & $\begin{array}{c}\text { \% relative to the } \\
\text { number of users } \\
\text { of WEB mobile } \\
\text { banking }\end{array}$ \\
\hline Check of account & 116 & 14.50 & 97.48 \\
\hline $\begin{array}{l}\text { Insight into balance and } \\
\text { turnover on loans }\end{array}$ & 19 & 2.38 & 15.97 \\
\hline $\begin{array}{l}\text { Transfer of funds between own } \\
\text { client accounts }\end{array}$ & 11 & 1.38 & 9.24 \\
\hline Monitoring of exchange rate & 8 & 1.00 & 6.72 \\
\hline Exchange transactions & 30 & 0.38 & 2.52 \\
\hline Cashless payments & 6 & 10.00 & 67.23 \\
\hline $\begin{array}{l}\text { Search for ATMs and bank } \\
\text { branches }\end{array}$ & 2 & 0.75 & 3.04 \\
\hline $\begin{array}{l}\text { The use of savings and loan } \\
\text { calculator }\end{array}$ & 4 & 0.50 & 1.68 \\
\hline Contracting of term deposits & 0.25 & \\
\hline
\end{tabular}

Source: Authors, based on the results of the survey.

The conducted survey enabled the identification of the basic causes of why a large number respondents on the territory of the Nisava District still does not decide to use WEB mobile banking services.Of the 681 respondents, who have declared themselves as not users of the services of WEB mobile banking, the majority of them thinks that the possibility of abuse in the payment is high, or that there is a great opportunity for hacker attacks and abuse of data exchanged between the user and the bank via the Internet. Even 590 of them believe that the abuse is possible. 
Also, a large number of respondents do not have enough confidence in whether the transaction they require on the phone will be really enforced, but also a large number of respondents declared that they do not have enough knowledge about the WEB mobile banking services, and how to realise its telephone banking transactions.

In addition to these reasons of non-use mobile banking applications, there are respondents who do not have smart telepfone, and in this way they are deprived of access to these services, and there are those respondents who have more confidence in the implementation of transactions in the banking counters, than in modern technology, as it can be seen Graph 5.

Graph 5 The Causes Due to Which Surveyed Respondents Do Not Use WEB Mobile Banking on the Territory of the Nisava District

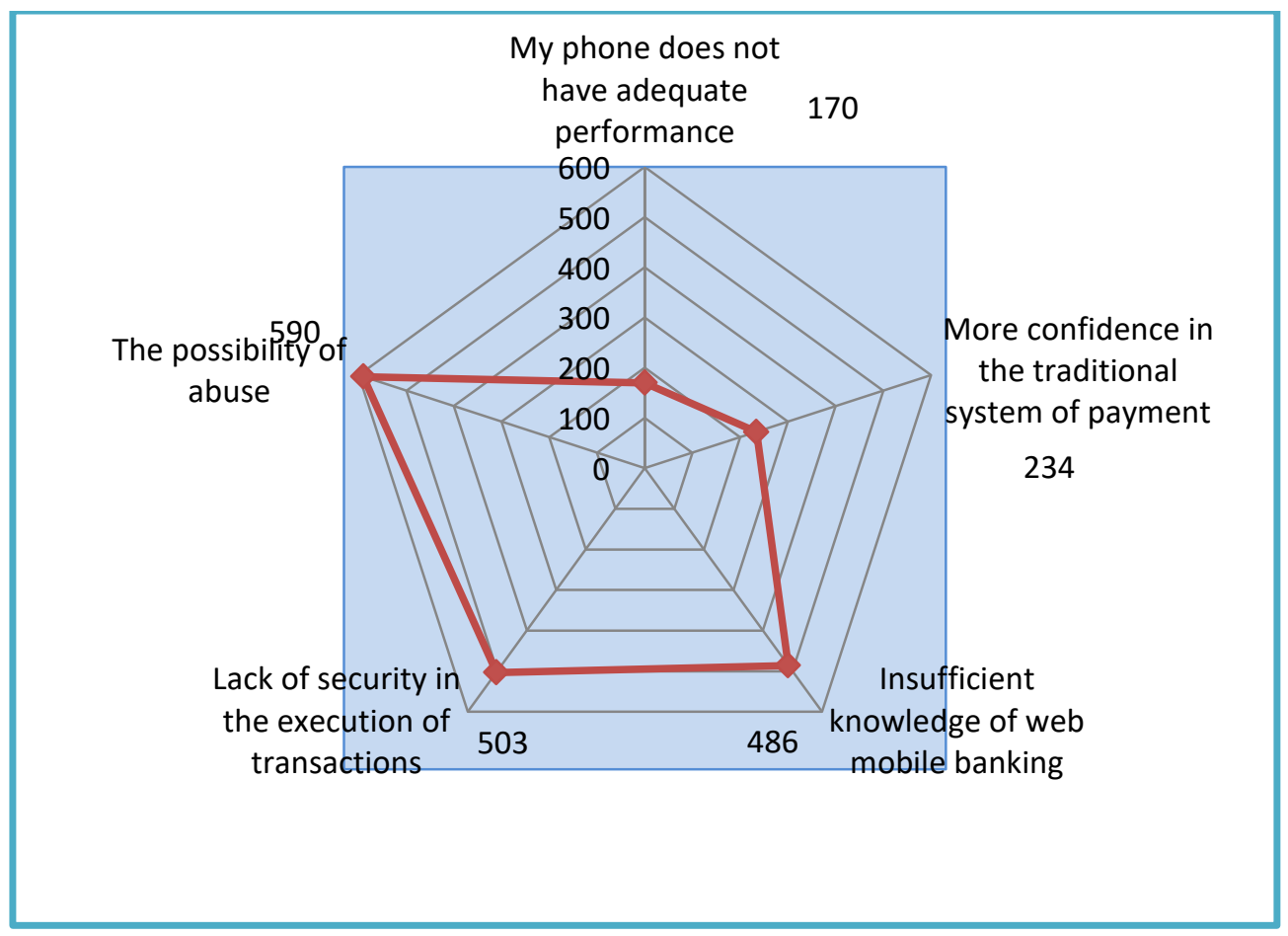

Source: Authors, based on the results of the survey.

To increase the number of mobile banking users in the Nisava District in the future period, on the basis of Graph 4, it can be concluded that it is necessary to indicate to clients the level of security that banks provide to their customers in the provision of mobile payments, but also it is necessary that the banks educate users about services of WEB mobile banking, given that a large number of respondents declared that they do not know enough about this type of banking.Bankers have to 
explain to their clients how to use mobile banking applications and to point to the advantage of this type of banking, in terms of availability of bank from any location and at any time, speed of implementation of transactions and lower commissions, which ultimately should lead to further penetration of mobile banking, both in the Nisava District, and in Serbia as a whole.

\section{Conclusion}

The penetration of smart phones among users has a major impact on them to develop a new distribution channel for banking services.In this way banks through the distribution of banking services via mobile phones tend to retain existing and win new clients, but also to create a greater degree of commitment to their clients.For clients through mobile banking services is provided the opportunity to lower costs at any time and from any location, execute payments they need.

Benefits of WEB mobile banking are the most used in Asian countries, where the proportion of the population who use this form of banking is significant. Also WEB mobile banking has a large number of users in America, while the number of users in the European Union is slightly lower, since the mobile banking application on their phones use $38 \%$ of the population of the Union.

When it comes to Serbia, in our country this kind of banking is still not sufficiently utilised, and according to the NBS for 2015, slightly more than 5\% of bank customers in Serbia use mobile banking application for the realisation of their transactions.

Regarding the Nisava District, of the total number of respondents in the poll, $14.88 \%$ of them said that they use WEB mobile banking. This is a significantly higher percentage than the percentage of clients who use these services in Serbia as a whole. It was expected, considering that the sophisticated technology is quickly accepted in major cities compared to smaller cities and villages.

In order to increase the number of WEB mobile banking users in Serbia and the Nisava District, it is necessary that banks instruct their customers about the benefits that this channel of distribution of banking services offer for clients. Banks must especially indicate to the clients about the level of safety which they provide to their clients in the execution of banking transactions by using mobile phones.

\section{References}

Acharya, S., Dunn, J., Hendrick, J. (2014) Mobile banking: Generation differences, Journal of Finance and Accountancy, Vol. 17. Dostupno na: http://www.aabri.com/manuscripts/142033.pdf, datum pristupa: 01.04.2016.

Barjaktarović, L. (2010) Upravljanje rizikom, Beograd,Univerzitet Singidunum. 
Becker, L. (2014) Mobile Banking 52 Success Secrets, Emereo Pty Limited, Brisbane.

Barnes, S. (2003) m-Business: The strategic implications of wireless technologies, Butterworth Heinemann, Amsterdam.

Barnes, S., Scornavacca, E. (2006) Uniwared Business: Cases in Mobile Business, IRM Press, London.

Curwen, P., Whalley, J. (2010) Mobile Telecomunications in a High-Speed World, Gower Publishing Limited, England.

Duggal, P. (2013) Mobile Banking \& Mobile Law, New Delhi,SAAKSHAR LAW PUBLICATIONS.

Drexelius, K. \&Herzig, M. (2001) "Mobile Banking and Mobile Brokerage Successful Applications of Mobile Business?”, International management \& Consulting, Vol.16, No. 2, p. 20-23.

Hadžić, M., Mladenović, V. (2014) Mobilno bankarstvo u Srbiji, stanje i potencijal, Časopis „Sinteza“, str. 125-129. Univerzitet Singidunum, Beograd.

Joshi, C. V. (2010) E-Finance: The Future is Here, New Delhi,SAGE Publication India.

King, B. (2013) Bank 3.0, Singapore, Marsall Cavendish Business.

Laukkanen, T. (2007) Internet vs mobile banking: comparing customer value perceptions, Business Process Management Journal, Vol 13, p. 788-797.

Mambi, J. A. (2010) ICT Law Book: A Source Book for Information and Communication Technologies \& Cyber Law in Tanzania and East African Community, Dar es Salaam,MkukinaNyota Publishers.

Mohapatra, S. (2013) E Commerce Strategy: Text and Cases, New York, Springer Science \& Business Media.

Sanders, D. (2014) Mobilno bankarstvo: Novi trend u savremenom bankarskom sektoru, Časopis „Bankarstvo“ Vol. 5, str. 86-109. Udruženje banaka Srbije, Beograd.

Šalić, R. (2012) Monetarnaekonomija ibankarstvo, Visokaposlovnaškolastrukovnihstudija u Čačku, Čačak.

http://www.tvojnovac.nbs.rs/latinica/20/kartice/el_bankarstvo.html, datum pristupa 31.03.2016.

http://ec.europa.eu/eurostat/tgm/table.do?tab=table\&plugin=1\&language=en\&pcod $\mathrm{e}=\mathrm{tin} 00099$, datum pristupa 31.03.2016.

http://www.statista.com/, datum pristupa 01.04.2016.

http://www.nbs.rs/export/sites/default/internet/latinica/35/statistika/pokazatelji/broj _korisnika.xls, datum pristupa 01.04.2016.

http://www.bancaintesa.rs/stanovnistvo/elektronsko-bankarstvo/intesa-sms-trajninalog.895.html , datum pristupa 01.04.2016. 


\section{ZNAČAJ MOBILNOG BANKARSTVA U NIŠAVSKOM OKRUGU}

Apstrakt: Promene u svetu tehnologije su bankama omogućile da koriste nove kanale pružanja bankarskih usluga svojim klijentima. Sa pojavom pametnih telefona, razvilo se WEB mobilno bankarstvo, koje daje mogućnost veće povezanosti između banke i klijenata. WEB mobilno bankarstvo sve više dobija na značaju, naročito u razvijenim zemljama, dok je taj proces kod nas znatno sporiji. Cilj ovog rada je da ukaže na prednosti koje WEB mobilno bankarstvo pruža korisnicima, ali i na njegovu slabu zastupljenost u Nišavskom okrugu i Srbiji uopste. Takođe identifikacijom osnovnih razloga slabe zastupljenosti mobilnog bankarstva na nasem području, ima se za cilj da se ukaže na koji se način može u budućem periodu ovo bankarstvo brže rasprostraniti među korisnicima. Da bi se definisani ciljevi rada postigli, u radu je pored deskriptivnog metoda, metoda kompilacije, komparacije, dedukcije i indukcije, koristišcen i statistički metod i to test nezavisnosti i koeficijent kontigencije.

Ključne reči: WEB mobilno bankarstvo, elektronsko bankarstvo, Srbija, Nišavski okrug.

\section{Authors' biographies}

Miloš Stojanović is a PhD student at the Faculty of Economics, University of Niš. He worked as a teaching associate at the High Business School in Leskovac and as a teaching assistant at the Faculty of Business Studies in Belgrade. He has published more then ten scientific papers as an author and coauthor, which were presented at domestic and international conferencies. He was awarded for academic results by the Ministry of Education, Science and Technological Development, Ministry of Youth and Sports and by the Faculty of Economics in Niš. He speaks English and Spanish language.

Marina Đorđević is an associate professor at the Faculty of Economics, University of Niš. She teaches Monetary and Public Finance. She earned her Master's degree and doctorate degree from the Faculty of Economics in Niš in 2002 and 2009, respectively. She has published a number of papers in scientific journals and has participated in national and international conferences in the country and abroad. She has participated in projects of the Faculty of Economics in Nis and the Ministry of Science, Republic of Serbia. 